Nationalities Papers, Vol. 26, No. 2, 1998

\title{
EDITORIAL NOTE: DECLINING INTEREST/GROWING IMPORTANCE
}

If making the headlines is a measure of interest, it is not necessarily an index of the level of importance. Ten years ago, The New York Times featured special sections of up to four or five full pages under such headings as "Evolution in Europe." In contrast, today's reportage is limited to single columns. News from the Russian Federation, the Central Asian Republics and individual East European countries is, at best, sporadic and dysjuncted. Clearly, interest has waned according to editorial policy. But does that mean the importance of the news has declined commensurably?

Thanks to geo-strategic considerations, the Soviet Union and the cluster of states subservient to it in Eastern Europe were of obvious concern to politicians, policymakers, and academics alike. No-one questioned that a change in the Kremlin, a shift in oil and gas production in Central Asia, a samizdat statement by a dissident anywhere in the Soviet bloc, or a strike and demonstration by miners or mothers of soldiers drafted to fight in Afghanistan was not of critical interest and, therefore, of some significance. Hence, by and large, this information was disseminated by the media, on the editorial assumption it needed to be circulated and commented upon.

The break-up of the Soviet empire and its satellite system attracted dramatic numbers of observers, many who had previously paid little attention to this part of the world other than in very broad and general terms. From about 1985, Mikhail Gorbachev's ascent to power till the collapse of the Berlin Wall, specialists and the public at large were riveted to their TV screens and/or voraciously ingesting long newspaper reports of the on-going denouement of the Soviet order, culminating in the miraculously (almost anti-climatic), non-violent demise of the USSR.

Thereafter, the media coverage visibly declined. Individual events sparked momentary attention if not interest and were on occasion infused with editorial "meaning": for example, suspicions about Boris Yeltsin's health; the violence of the crack-up of Yugoslavia; and, of course, the tragic war in Chechnya. With but few exceptions, these events were presented for their drama rather than for their on-going significance. For example, now that the fighting has ceased in Chechnya, the country has fallen beyond the media's reach: the convoluted and dangerous almost daily negotiations between Grozny and Moscow are left unreported-although a kidnapping here and there is given an inside, 3-4 sentence by-line. The overall impact of Chechnya on the dynamics of the continuing weakening of the Russian Federation's central authority in the face of rising regional (cum ethnic) centrifugal power is totally ignored as if it had no bearing on the U.S. The same can be said of the international struggle for control over gas and oil in the Caspian region. Once a 
month, perhaps, a mention of this is made, squeezed in between long tracts on the legal and "cosmic" ramifications of the daily soap opera of the White House.

In some ways, the profession vis-à-vis the public is being forced back to where it was in 1941, prior to World War II (according to the U.S. calendar). In those distant days, less than a handful of universities offered courses on the USSR, a few more offered an occasional course on Eastern Europe. Language study was all but invisible. That part of the World seemed remote from concerns of national security. That myopia changed, thanks to the war and the Cold War decades. But now the pendulum seems to be swinging back, as if no lessons had been learned from the pre-1941 diplomatic isolationism and, worse, intellectual parochialism.

This journal can do little more than underscore the severity of this present trend towards a neo-ignorance, one aided and abetted by the media; a development already noted by others prior to this editorial caveat. Nevertheless, it can, modestly, issue by issue, persistently emphasize the importance of knowledge and understanding of the dynamics of ethnopolitics - as a major force - in the territorium of the former Soviet empire, despite the abysmal lack of reportage for the public at large and the rapidly shrinking, learning opportunities for the student population who may grow up with a seriously unbalanced view of the world.

Eastern Europe, the Balkans, the Baltic region, the Caucasus, and Central Asia should not simply fall off the screen and the front pages because of the absence of the Soviet Union. This is to commit an old sin anew. On account of the Cold War, the media neglected large swaths of the world, treating these regions as tertiary to the bi-polar drama raging on the planet. This caused serious blind-spots with resultant policy fiascos. Now this tendency threatens to cast much of the ex-communist, Soviet-dominated world into a similar self-imposed limbo, to be looked at on occasion when events "merit" our attention. 